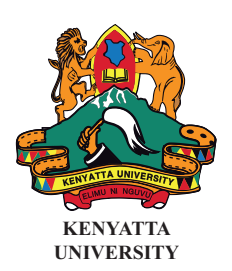

ISSN 2663-0826
CHEMCHEMI

International Journal of Humanities and Social Sciences

\title{
RESEARCHING RELIGION-TERRORISM NEXUS FOR SUSTAINABLE GLOBAL SECURITY MANAGEMENT: IS ISLAM BEING FALSELY ACCUSED?
}

\author{
Fuchaka Waswa
}

\begin{abstract}
There is no doubt that terrorism is a peculiar and serious threat to global peace, security and by extension human well-being. Despite concerted military efforts by governments that have borne the brunt of its attacks, suppressing let alone elimination of terrorism has remained elusive. This limited success that has been achieved by seemingly targeting the terrorist per se implies that the root cause may not have been identified. While terror attacks have been done by people of various political and religious persuasions, the frequencies with which perpetrators appear to directly or indirectly invoke the great religion of Islam is worrying. Accordingly, it is this paper's hypothesis that the root cause of terrorism particularly the kind meted in non-Muslims is inherent in the religious doctrine that the terrorists have embraced. Therefore, independent global research agenda needs to focus on this dimension in order to prove or dispel the above hypothesis. This paper makes reference to reported terror attacks where responsibility has been somehow claimed by people who profess the Islamic faith, whether rightly or otherwise in order to hopefully open debate on the possible role doctrine in directly or indirectly encouraging violence against people of other faiths - whether for religious or socio-political goals. Ultimately this dialogue should yield insights on how to effectively eliminate terrorism from its root causes and enhance peaceful coexistence in today's multi-cultural dispensation across the world and in particular, Kenya.
\end{abstract}

Keywords: Terrorism, Messenger, Doctrine, Security, Peaceful Coexistence

\section{Introduction}

Due to, perhaps, different motivations of terrorists, there is no universal agreement regarding the definition of terrorism. The common understanding of terrorism is the use of violent acts to frighten people in a given area as a way of trying to achieve a political goal (http://www.merriam-webster.com/dictionary/terrorism). The US State Department, views terrorism as premeditated, politically motivated violence perpetrated against non-combatant targets by sub-national groups or clandestine agents (http://www.state.gov/documents/organization/65464.pdf). The North Atlantic Treaty Organization (NATO) defines terrorism in the AAP-06 NATO glossary of terms and definitions as "the unlawful use or threatened use of force or violence against individuals or property in an attempt to coerce or intimidate governments or societies to achieve political, religious or ideological objectives (http://nso.nato.int/nso/zPublic/ap/aap6/ AAP-6.pdf). A more comprehensive definition is provided in the United Nations Security Council Resolution 1566 of 2004 that condemned terrorist acts as: "criminal acts, including against civilians, committed with the intent 
to cause death or serious bodily injury, or taking of hostages, with the purpose to provoke a state of terror in the general public or in a group of persons or particular persons, intimidate a population or compel a government or an international organization to do or to abstain from doing any act, which constitute offences within the scope of and as defined in the international conventions and protocols relating to terrorism, are under no circumstances justifiable by considerations of a political, philosophical, ideological, racial, ethnic, religious or other similar nature".

Peter Chalk quoted in the World Watch Institute (2005) hypothesised another potentially devastating kind of terrorism, when he noted that terrorists may have greater opportunities to use food as a weapon of mass destruction - in what he called agro-terrorism. Food has this potential given the amount of food that circulates around the world for human consumption. Similarly, the author postulates that the international community should not ignore the destruction that could occur were public physical infrastructure like water supply reservoirs be choice weapons in what may be called environmental terrorism. Poisoning such systems could wipe out an entire city. Terrorism can also be political - when people use terror especially on unarmed civilians to force through their political agenda. This kind of terrorism is however sometimes wrongly equated to freedom struggles. Racial and religion-driven terrorism are perhaps the oldest kind. Recent examples include the pogroms including the holocaust the Jews went through during the Second World War period under the Nazis in Europe, and under Muslims in the Middle East and North Africa (Peters, 1984).

In the above definitions, the drivers of terrorism are myriad. They can be political, religious, sectarian and even cultural. Although political-terrorism can be solved through political negotiations and settlement, managing religious terrorism appears more difficult to achieve because of the diametrical differences in cultural and religious orientations among different people groups. This paper focuses on what appears to be Islam-driven terrorism, given the importance it has gained around the world in recent times. It is however the author's opinion that profiling Muslims as terrorists because of the acts of a few people within their ranks would be erroneous. In the past other religions too have also engaged in terrorism. One example is captured by Forbush (1926) thus: "Disregarding the maxims and the spirit of the gospel, the papal church, arming herself with the power of the sword, vexed the church of God (apostolic church) and wasted it for several centuries, a period most appropriately termed in history, the Dark Ages. Preaching the pure gospel devoid of human-made traditions and assumptions was taken as heresies and the price was death, after very inhuman torture, designed to make bible-based believers to recant." The potential nexus between such religions and terrorism equally needs to be researched. The focus of this paper is however Islam, given the negative publicity this great religion has received in the wake of terrorism attacks around the world.

Although current global terrorism is popularly blamed on various reasons such as economic and political marginalization, unemployment and poverty, the frequency with which the great religion of Islam continues to be directly or indirectly, falsely or rightfully linked to it (http://www.thereligionofpeace.com/attacks/attacks.aspx?) provides a basis for investigating the possibility of their being a correlation between terrorism and this religion. The relevance of this interrogation is informed by the negative effects insecurity can have on human well-being (http://www.millenniumassessment.org/en/Framework.html), whose conventional components are generally listed as: having materially enough for a decent life, enjoying good health, having good social relations, feeling safe and secure, and having the ability to make choices and preferences (Alcamo et al., 2003). These human well-being components are mutually inclusive. Not having one of them directly affects the remaining four components with the net effect of undermining overall human development. The clusters of disadvantage described by Chamber (1983) are what this paper refers to as components of human ill-being. Regardless of thematic specialization, development research needs to shift people from the state of ill-being to that of well-being (Figure 1). Without 
security and peace labour cannot be dispensed to deliver on all other components of human well-being.

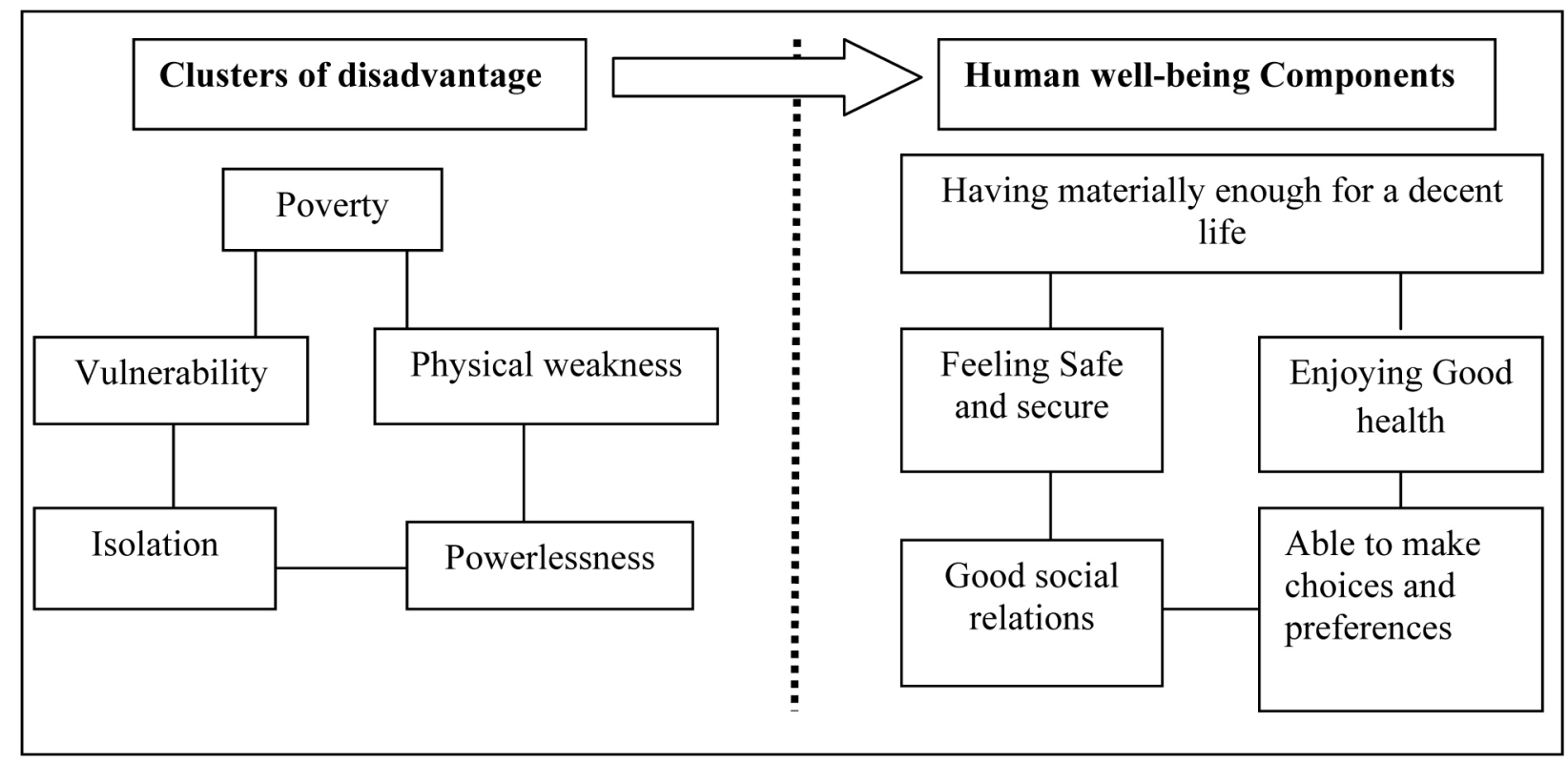

Figure 1: Conceptualizing the human ill-being to human well-being shift

Source: Synthesized from reviewed literature

For instance, living in an environment where one is vulnerable to insecurity, war and conflict (i.e. not feeling safe and secure) the tendency is always outmigration. People tend to abandon their productive engagements like agriculture, trade, research, innovation, education and academic programmes, and other engagements that naturally create wealth and enhance living standards. The material lack that often follows is, in part, responsible for the challenge of economic refugees facing several recipient countries. In particular recipient nations must provide housing, health care, work/employment, language skills and education from national taxes (http://www.euronews. com/2016/11/01/refugees-in-germany-from-desperation-to-economic-fortune). In some cases, the burden on social welfare and changing socio-cultural landscapes can provoke negative reactions from citizens of recipient countries. This dimension has, in part, been comprehensively discussed by Rother et al. (2016) based on their reflection on the refugee crisis in the Middle East and North Africa

The bigger yet subtle danger, to western civilization is religion-driven infiltration and conquest, which is being ironically applauded and nurtured by blind political correctness based on the imperative to uphold western values of democracy, multi-culturalism, protection of human rights and liberalism (Youssef, 2017). That terrorism is a serious threat to global peace and security is now a topical issue around the world. Ritchie et al., (2020) observed that an estimated 26,445 people died from terrorism globally in 2017. Neumann (2008) rightly observed that attempts to derive wide-ranging insights about the causes and possible solutions for particular violent conflicts based solely on their 'terroristic' manifestations must fail. This, in part, explains the importance this paper attaches on the need to find the root causes of terrorism in different situations. The inhuman and illogical nature of terrorism was perhaps better understood by the international community on $11^{\text {th }}$ September 2001 when "Islamic hijackers" steered two passenger planes into the World Trade Centre and the Pentagon in the United States, killing hundreds on impact and eventually thousands when the towers collapsed (https://www.cia.gov/library/publications/resources/9-11tenth-anniversary/9-11-Brochure.pdf).

Global reporting seems to suggest that terrorism related crimes continue to be security concerns in several nations 
around the world. In July 2016 a terrorist ploughed into a crowd in Nice (France) killing at least 84 people, including children. In March 2016, a Taliban splinter group Jamaat-ul-Ahrar claimed responsibility when a suicide bomber targeting people celebrating Easter holiday killed 70 people, mostly Muslims and wounded about 300 in Lahore, in Pakistan (http://www.bbc.com/news/world-asia-35910124). The terror attacks in Brussels (March 2016), France (Charlie Hedbo January 2015 and November 2015 Paris Attacks), Orlando massacre in the USA (June 2016), recurrent street stabbing of Jews in Israel (http://edition.cnn.com/2017/07/21/middleeast/old-cityprayer-restrictions-imposed/index.html), the recent west minister attack in the UK (http://www.bbc.com/news/ uk-39365569), sporadic yet deadly attacks on non-Muslims targets and the bloodletting pitting various Islamic sects and clans in predominantly Islamic nations and the atrocities of the caliphate-driven Islamic State (ISIS) should cause the international community to begin asking hard questions on the possibility of there being a positive correlation between Islamic doctrine and terrorism.

In Kenya, Omar (2016) has compiled at least 30 terrorist attacks since the 1998 bombing of the American Embassy in Nairobi, in which 213 people were killed and over 5000 wounded. Al-Qaida claimed responsibility. The targets of these terror attacks have often been places or persons not considered Islamic, collateral damage notwithstanding. For instance, on $14^{\text {th }}$ November, 2002 Islamist terrorist attacked at an Israeli-owned hotel in Kikambala, Mombasa, killing 15 people. On $5^{\text {th }}$ November 2011 suspected Islamists hurled two grenades at the East African Pentecostal Church in Garissa town, killing 2 and injuring 5 people. Further on $24^{\text {th }}$ November 2011, twin grenades targeted Holiday Inn Hotel and a shop in Garissa, killing 3 people and injuring at least 27 others. On $21^{\text {st }}$ September 2013 Al-shabaab claimed responsibility when armed gunmen attacked the Westgate Shopping Mall in Nairobi, killing at least 69 people identified on the basis of religion and injuring more than 175. On $16^{\text {th }}$ June 2014 at least 48 people were killed when suspected Al-shabaab militants from Somalia stormed into Mpeketoni a Kenyan coastal town and launched a major assault on a police station, hotels and government offices. On $22^{\text {nd }}$ November 2014, gunmen attacked a bus travelling from Mandera to Nairobi killing 28 persons isolated from Muslim commuters on the same bus. On $2^{\text {nd }}$ December 2014, Al-Shabaab militants attacked and killed 36 quarry workers, many of whom were non-Muslims, near Mandera Town.

The nation was shocked on $2^{\text {nd }}$ April 2015 when gunmen stormed the Garissa University College killing 148 people (mostly Christian students separated from their Muslim colleagues) and injuring at least 79 others. At dawn on $15^{\text {th }}$ January 2016, Al-Shabaab militants overran a Kenyan army base in the town of El Adde in Somalia inflicting heavy losses on the Kenya Defence Forces. The terrorist nature of the attack was in the way the killing was done and subsequent posting of mutilated and gory bodies on social media to psychologically terrorize the nation. The terror attacks at the DusitD2 complex (Westland, Nairobi) in January 2019, which left more than 20 people dead; the Christchurch mosque shootings in New Zealand in march 2019, which left 50 people dead; and the April 2019 Sri Lanka church attack, which left 250 people dead are yet the most recent ugly faces of terrorism.

As recent as January 2020, Al-Shabaab jihadists have targeted public busses and isolated Christians from Muslims before killing the former in cold blood in Kenya's north eastern towns of Garissa and Wajir. In other cases, nonMuslims, including teachers posted in those areas have been attacked and killed in their homes (The East Africa, 2020). That the main stream media and government prefer to identify the victim as non-locals and not as Christians is indicative of how far political correctness can be invoked to appease perpetrators of serious crime. Is it possible that this narrative of calling a spade a small spoon is driven by fear of reprisals from the enemies of peaceful coexistence who may have captured the state? With such defeatist approaches, eliminating terrorism from its root causes may remain a mirage. 
While actual responsibility for most of the attacks indicated above may not have been $100 \%$ confirmed, evidence based on those who claimed responsibility, or those arrested often points to persons who profess the Islamic faith. Scholars need to investigate whether this is a mere coincidence or a direct result of religious bigotry. The suicidebased bloodletting in towns and worship places in few predominantly Islamic-Arabic nations as widely publicized in the international media, provides yet another research agenda on whether intra-religious differences can be a cause for extreme violence. Few rare incidents when some honourable Muslims have shielded non-Muslims against attacks from within their religious ranks indicate that people have the inherent ability to refuse being indoctrinated and instead remain humane and care for the sanctity of life, their religious differences notwithstanding.

That the world has continued to witness incomprehensible terror attacks suggests that our humanness can be so severely altered. A lasting solution is yet to be found against this threat to modern civilisation. English (2016) opines that a simultaneous approach that integrates terrorism, counter-terrorism, and the relationship between them, and to do so in truly multi-disciplinary manner with an eye to policy seriousness is what is needed. One area that policy makers seem to conveniently avoid is the possible connection between terrorism and religious doctrines. Whether this inertia is occasioned by the deception inherent in "political correctness" within liberal democracies remains an open question.

Natan (undated) has complied on line at least 164 Jihad verses in the Quran, which deserve a careful analysis and critic. Jihad in this context means a war or struggle against unbelievers; or the spiritual struggle within oneself against sin; or expressing effort in Muslim thought; or struggle on behalf of Allah and Islam (https://www.google. $\mathrm{com} / \# \mathrm{q}=\mathrm{jihad}+$ definicion). While striving hard against oneself to earn divine benefits is what is typically amplified when questions arise following terror attacks, plain reading of the Quran seems to emphasise the dimension of physical violence against unbelievers. In an attempt to manage escalating insecurity crisis, the security agencies in Kenya have been blamed by the human rights groups for excesses and abuse of human rights including extrajudicial killings, arbitrary detentions, and torture of purported terrorists particularly during counter-terrorism operations in Nairobi, the coast and the northeast regions (https://www.hrw.org/world-report/2016/country-chapters/kenya). Whether this blame deserves merit or not is perhaps subject to political and judicial discussion. In essence, through research, guidelines on striking the balance between the rights of both the terrorists (if any) and their victims in the context of the law and natural justice can be developed.

Various sources have documented the possible relationship between Islamic doctrine and terrorism; including violation of human rights from various angles (Shayesteh, 2009; Hammond, 2010; Swagart, 2010; Lindsey, 2011; Caschetta, 2015; and http://barenakedislam.wordpress.com). According to the United States Commission on International Religious Freedom (2019) religious intolerance and persecution around the worldwide is accelerating. In this context, dialogue and research on global security needs to also clearly distinguish between politically acceptable terms like extremists, fundamentalists, radicals and moderates on matters religion. For politicising these terms, it would seem as if a religious continuum exists upon, which somebody's level of religious adherence could be estimated. Doctrinal research would need to indicate whether those who call themselves "true believers" constitute the radicals, extremists or otherwise and whether their actions are sanctioned by the doctrines and traditions they have embraced and seek to enforce or are mere criminal acts.

\section{Methodology}

In an attempt to provoke debate and research on whether Islamic doctrine and terrorism may be positively correlated, this paper attempted to comb through the Quran picking out verses which from plain reading directly 
or indirectly encourage Muslims to be violent against non-Muslims. Since some verses are numbered and worded differently depending on the version, the verses listed in this paper were cross-checked against authoritative hard copy of "The Holy Quran, Text, Translation and Commentary by Abdullah Yusuf Ali, reprinted in 2011" and the "Interpretations of the meanings of The Noble Quran in the English Language by Dr. Muhammad Muhsin Khan and Dr. Muhammad Taqi-ud-Din Al-Hilali, 1996). Examples of global terror attacks provided in the introductory part of this paper were compiled from various internet sources, including media records. Observations from other authors have been cited and referenced accordingly. This theoretical paper has isolated some 48 verses which from plain reading and interpretation directly urge, cause, encourage or blackmail Muslims to be violent against nonMuslims and other people who revile or cause mischief to Islam. So that readers' opinions are not influenced, the author has not attempted to provide interpretation to these verses or link each verse to any particular terror attack. Instead, the assumption was made that readers are familiar with current global affairs including terror trends reported regularly by media agencies. Cognisant of Das et al. (2009) analysis of prejudices against people groups in view of terror-related news, those who interact with this article are encouraged to be open minded, sober and intellectually focus on the issues in this envisaged dialogue of religion and security in order to meaningfully contribute to the global quest for sustainable peaceful co-existence, people's different religious persuasions notwithstanding.

\section{Discussion}

That the Islamic doctrine could be the root cause of terrorism around the world can be inferred from diligent research of Quran verses and Islamic traditions detailed in the hadith. A glimpse in what a few selected verses suggest is chronologically listed below. The author has not attempted to interpret these verses but invite readers to make their own judgement based on plain reading. However, the italics are the author's emphasis based on the gist of the paper. For purposes of guidance, the first number in the [ ] is the Chapter, while the subsequent is the verse(s).

1. [2:216] Fighting is enjoined on you, and it is an object of dislike to you; and it may be that you dislike a thing while it is good for you, and it may be that you love a thing while it is evil for you, and Allah knows, while you do not know.

2. [2:244]. And fight in the way of Allah, and know that Allah is hearing, ...

3. [3:142]. Did you think that ye would enter Heaven without God testing those of you who fought hard (in His Cause) and remained steadfast?

4. [3:152] And certainly Allah made good to you His promise when you slew them by His [Allah's] permission [during a Jihad battle], until when you became weak-hearted and disputed about the affair and disobeyed after He [Allah] had shown you that which you loved; of you were some who desired this world and of you were some who desired the hereafter; then He [Allab] turned you away from them that He might try you; and He has certainly pardoned you, and Allah is Gracious to the believers.

5. [3:167] And that He might know the hypocrites; and it was said to them: Come, fight in Allah's way, or defend yourselves. They said: If we knew fighting, we would certainly have followed you. They were on that day much nearer to unbelief than to belief. They say with their mouths what is not in their hearts, and Allah best knows what they conceal.

6. [3:169] And reckon not those who are killed in Allah's way as dead; nay, they are alive (and) are provided sustenance from their Lord

7. [4:74-77] Therefore let those fight in the way of Allah, who sell this world's life for the hereafter; and whoever fights in the way of Allah, then be he slain or be he victorious, We shall grant him a mighty reward. And what reason have you that you should not fight in the way of Allah and of the weak among the men and the women 
and the children, (of) those who say: Our Lord! cause us to go forth from this town, whose people are oppressors, and give us from Thee a guardian and give us from Thee a helper. Those who believe fight in the way of Allah, and those who disbelieve fight in the way of the Satan. Fight therefore against the friends of the Satan; surely the strategy of the Satan is weak. Have you not seen those to whom it was said: Withhold your hands, and keep up prayer and pay the poor-rate; but when fighting is prescribed for them, lo! a party of them fear men as they ought to have feared Allah, or (even) with a greater fear, and say: Our Lord! why hast Thou ordained fighting for us? Wherefore didst Thou not grant us a delay to a near end? Say: The provision of this world is short, and the hereafter is better for him who guards (against evil); and you shall not be wronged the husk of a date stone

8. [4:89] They desire that you should disbelieve as they have disbelieved, so that you might be (all) alike; therefore, take not from among them friends until they fly (their homes) in Allah's way; but if they turn back [to their homes], then seize them and kill them wherever you find them, and take not from among them a friend or a helper

9. [4:95] The holders back from among the believers, not having any injury, and those who strive hard [Jihad] in Allah's way with their property and their persons are not equal; Allah has made the strivers with their property and their persons to excel the holders back a (high) degree, and to each (class) Allah has promised good; and Allah shall grant to the strivers [i.e., Jihadist] above the holders back a mighty reward

10. [4:100-101] And whoever flies in Allah's way [forsakes his home to fight in Jihad], he will find in the earth many a place of refuge and abundant resources, and whoever goes forth from his house flying to Allah and His Apostle, and then death overtakes him [in Jihad], his reward is indeed with Allah and Allah is Forgiving, Merciful. And when ye go forth to war in the land, it shall be no crime in you to cut short your prayers, if ye fear lest the infidels come upon you; Verily, the infidels are your undoubted enemies!

11. [4:104] And be not weak hearted in pursuit of the enemy; if you suffer pain, then surely they (too) suffer pain as you suffer pain, and you hope from Allah what they do not hope; and Allah is Knowing, Wise.

12. [5:33] The punishment of those who wage war against Allah and His apostle and strive to make mischief in the land is only this, that they should be murdered or crucified or their hands and their feet should be cut off on opposite sides or they should be imprisoned; this shall be as a disgrace for them in this world, and in the hereafter they shall have a grievous chastisement

13. [5:35] O you who believe! be careful of (your duty to) Allah and seek means of nearness to Him and strive hard [at Jihad] in His way that you may be successful

14. [5:51]. Says, O believers! Take neither Jews nor Christians as your (protecting) friends: they are only (protecting) friends of one another. Whoever of you disobeys this commandment will be counted as one of them. Surely Allah does not guide the wrongdoers

15. [5:82] Certainly you will find the most violent of people in enmity for those who believe (to be) the Jews and those who are polytheists [while they are converted to Islam on pain of death].

16. [8:12]. When your Lord revealed to the angels: I am with you, therefore make firm those who believe. I will cast terror into the hearts of those who disbelieve. Therefore, strike off their heads and strike off every fingertip of them.

17. [8:15] O you who believe! when you meet those who disbelieve marching for war, then turn not your backs to them.

18. [8:17] So you did not slay them, but it was Allah Who slew them, and you did not smite when you smote (the enemy), but it was Allah Who smote, and that He might confer upon the believers a good gift from Himself; surely Allah is Hearing, Knowing

19. [8:65-66] O Prophet! urge the believers to war; if there are twenty patient ones of you they shall overcome two 
hundred, and if there are a hundred of you they shall overcome a thousand of those who disbelieve, because they are a people who do not understand [in other words, "do not understand totalitarian ideologies like Islam". For the present Allah has made light your burden, and He knows that there is weakness in you; so if there are a hundred patient ones of you they shall overcome two hundred, and if there are a thousand they shall overcome two thousand by Allah's permission, and Allah is with the patient.

20. [8:67] It is not fit for a prophet that he should take captives unless he has fought and triumphed in the land; you desire the frail goods [i.e., ransom money] of this world, while Allah desires (for you) the hereafter; and Allah is Mighty, Wise

21. [9:5]. So when the sacred months have passed away, then slay the idolaters wherever you find them, and take them captives and besiege them and lie in wait for them in every ambush, then if they repent and keep up prayer and pay the poor-rate, leave their way free to them; surely Allah is Forgiving, Merciful.

22. [9:12-14] And if they break their oaths after their agreement and (openly) revile your religion, then fight the leaders of unbelief - surely their oaths are nothing — so that they may desist [12] What! will you not fight a people who broke their oaths and aimed at the expulsion of the Apostle, and they attacked you first; do you fear them? But Allah is most deserving that you should fear Him, if you are believers [13]. Fight them, Allah will punish them by your hands and bring them to disgrace, and assist you against them and heal the hearts of a believing people [14].

23. [9:20] Those who believed and fled (their homes), and strove hard [Jihad] in Allah's way with their property and their souls, are much higher in rank with Allah; and those are they who are the achievers (of their objects).

24. [9:29]. Fight those people of the Book (Jews and Christians) who do not believe in Allah and the Last Day, do not refrain from what has been prohibited by Allah and His Messenger and do not embrace the religion of truth (Al-Islam), until they pay Jizya (protection tax) with their own hands and feel themselves subdued

25. [9:38-39] O you who believe! What (excuse) have you that when it is said to you: Go forth in Allah's way [to Jihad], you should incline heavily to earth; are you contented with this world's life instead of the hereafter? But the provision of this world's life compared with the hereafter is but little. If you do not go forth [to go on Jihad], He will chastise you with a painful chastisement and bring in your place a people other than you [to go on Jihad], and you will do Him no harm; and Allah has power over all things

26. [9:41]. March forth whether you are equipped lightly or heavily and make Jihad in the way of Allah with your wealth and your persons. That is best for you if you understand.

27. [9:73]. O Prophet! strive hard [Jihad] against the unbelievers and the hypocrites and be unyielding to them; and their abode is hell, and evil is the destination.

28. [9:88]. But the messenger and those who believe with him strive hard [in Jihad] with their property and their persons; and these it is who shall have the good things and these it is who shall be successful.

29. [9:111]. Surely Allah has bought of the believers their persons and their property for this, that they shall have the garden; they fight in Allah's way, so they slay and are slain; a promise which is binding on Him in the Taurat (Old Testament of the Bible) and the Injeel (New Testament of the Bible) and the Quran; and who is more faithful to his covenant than Allah? Rejoice therefore in the pledge which you have made; and that is the mighty achievement

30. [9:123] O you who believe! fight those of the unbelievers who are near to you and let them find in you hardness; and know that Allah is with those who guard (against evil).

31. [22:58]. And those who leave their homes for the cause of Allah, and are then slain or die, Allah will, surely, provide for them a goodly provision. And, surely, Allah is the Best of providers.

32. [25:52]. So obey not the unbelievers and fight strenuously with them in many a strenuous fight.

33. [29:6]. And whoever strives hard [in Jihad], he strives only for his own soul; most surely Allah is Self-sufficient, 
above (need of) the worlds.

34. [29:69]. And (as for) those who strive hard [in Jihad] for Us [Allah], We will most certainly guide them in Our ways; and Allah is most surely with the doers of good.

35. [33:23]. Of the believers are men who are true to that which they covenanted with Allah. Some of them have paid their vow by death (in battle), and some of them still are waiting; and they have not altered in the least

36. [33:60-62] If the hypocrites, those in whose hearts is malice and the scandal mongers of Medina do not desist; We shall rouse you against them, and their days in the city - as your neighbours - will be numbered [60] They shall be cursed wherever they are found and they shall be seized and killed mercilessly. [61] This has been the Way of Allah regarding such people among those who lived before you, and you will never find any change in the Way of Allah.

37. [44:51-57]. As for the righteous, they will be in a secure place [51] among gardens and springs, [52] dressed in fine silk and rich brocade, sitting face to face. [53] Such shall be their place! And We shall wed them to Hourin-Ayn (damsels with beautiful big and lustrous eyes). [54] There, in full peace, they shall call for every kind of fruit; [55] and after having prior death in the world, they shall taste death no more; and He (Allah) will protect them from the torment of hell [56] as a grace from your Lord, and that will be the supreme achievement. [57]

38. [47:4]. So when you meet in battle those who disbelieve, then smite the necks until when you have overcome them, then make (them) prisoners, and afterwards either set them free as a favour or let them ransom (themselves) until the war terminates. That (shall be so); and if Allah had pleased He would certainly have exacted what is due from them, but that He may try some of you by means of others; and (as for) those who are slain in the way of Allah, He will by no means allow their deeds to perish

39. [47:35]. Be not fainthearted then; and invite not the infidels to peace when ye have the upper hand: for Allah is with you, and will not defrand you of the recompense of your works...

40. [48:16]: Say to those of the dwellers of the desert who were left behind: You shall soon be invited (to fight) against a people possessing mighty prowess; you will fight against them until they submit; then if you obey, Allah will grant you a good reward [booty]; and if you turn back as you turned back before, He will punish you with a painful punishment.

41. [48:17]: There is no blame for the blind, nor is there blame for the lame, nor is there blame for the sick (that they go not forth to war). And whoso obeyeth Allah and His messenger [by going on Jihad], He will make him enter Gardens underneath which rivers flow; and whoso turneth back [from Jihad], him will He punish with a painful doom.

42. [49:15]. Verily the true believers [are] those only who believe in Allah and his messenger and afterwards doubt not; and who employ their substance and their persons in the defence of God's true religion: These are they who speak sincerely.

43. [52:17-20] As for the righteous, they will be in Gardens and bliss [17] rejoicing in what their Lord has given them and their Lord shall shield them from the torment of hell [18] It will be said to them: "Eat and drink to your heart's content, this is the reward for your good deeds." [19] They shall recline on couches arranged in rows; and We shall wed them with beautiful Huris (damsels) [20]

44. [55:55-76]. Then, $O$ jinn and men, which of your Lord's favours will both of you deny? [55]. Therein will be bashful virgins, whom neither any man nor jinn has touched before [56] Then, $O$ jinn and men, which of your Lord's favours will both of you deny? [57] So beautiful as though they were rubies and corals [58] Then, O jinn and men, which of your Lord's favours will both of you deny?[59] Could the reward for goodness be anything but goodness?[60]. Then, O jinn and men, which of your Lord's favours will both of you deny?[69] In each of them, there will be chaste and beautiful virgins. [70] Then, $O$ jinn and men, which of 
your Lord's favours will both of you deny?[71] Huris (beautiful damsels) sheltered in their tents. 172] Then, $O$ jinn and men, which of your Lord's favours will both of you deny?[73] Whom neither man nor Jinn has ever touched before.[74] Then, O jinn and men, which of your Lord's favours will both of you deny?[75] Reclining on green cushions and beautiful fine carpets.[76]

45. [61:4]. Surely Allah loves those who fight in His way in ranks as if they were a firm and compact wall.

46. [61:11]. You shall believe in Allah and His messenger, and struggle hard in Allah's way [Jihad] with your property and your lives; that is better for you, did you but know!

47. [66:9]. O Prophet! strive hard against the unbelievers and the hypocrites, and be severe against them; and their abode is hell; and evil is the resort.

From plain reading and literal interpretation, these verses appear to encourage and blackmail Muslims to be violent against non-Muslims. In addition, Muslims themselves face terrorism of various kinds such as excommunication from family, banishment, persecution, disinheritance, dispossession and even death; when they reject Islam because no other religion is to be accepted except Islam (Quran; 2:217; 3:85, 90-91, 4:89, 140, 5:54 and 9:73-74). Despite this wealth of evidence that seems to link Islamic teachings to violence, war and abuse of human rights, Muslims often vehemently insist that Islam is a religion of peace and those carrying out such terror attacks are not true Muslims. A popular verse quoted though "not in entirety" is Quran 5:32, thus, "On account of that incident, We ordained for the Children of Israel that [whoever kills a person], except as a punishment for murder or mischief in the land, [it will be written in his book of deeds as if he had killed all the human beings on the surface of the Earth and whoever will save a life shall be regarded as if he gave life to all the human beings on the surface of the Earth]. Yet, even though Our Messengers came to them one after the other with clear revelations, it was not long before, many of them committed excesses in the land'. For having the tendency to quote only the sections in parenthesis of this verse, the apologists are deliberately involving themselves in deception about the real meaning of this verse. Plain reading of the whole verse seems to suggest that Jews can be killed in retaliation for murder or when they engage in mischief. However, what is meant by "mischief" is not explained, thus providing loopholes for abuse of human rights particularly freedom of religion, expression, conscience, associations and relationships.

Research needs to establish whether this approach of misrepresenting verses is in any way related to the taqqiya principle (also referred to us hudna or the Quraish model). According to (http://www.islamic-laws.com/taqiyah.htm) the rule that allows one to hide his/her religion/faith when one's life is in danger is called taqqiyah. In practice this rule also extends to allow one to hide his/her real intentions or even lie as long as that advances one's religion or makes the religion look good. Hudna is also generally defined as a "temporary treaty" (or cease fire) which can be approved or abrogated (summarily and unceremoniously broken) by Islamic religious leaders, depending on whether or not it serves the interests of the religion. According to Shayesteh (2009), Lindsey (2002 and 2011) and Caschetta (2015), taqqiya is meant to allow Muslims to buy time, deceive and pacify their ignorant and unsuspecting "enemies" in order to conquer them at the opportune time when they least expect. Application of taqqiya in contemporary times is reflected in the "Palestinian" narrative about the Oslo accord. The Palestinian Authority Minister of Religious Affairs affirmed that by signing the agreements with Israel, they knew how to walk "the right path, which leads to achievement, exactly like the Prophet did in the Treaty of Hudaybiyyah."- a 10-year truce that Muhammad, made with the Quraish tribe of Mecca, only to violate it after two years by deceitfully attacking and conquering Mecca. The Minister ended his comparison by expressing the view that the Hudaybiyyah agreement is not just past history, but that it is the example and the model to be followed ((http://palwatch.org/main.aspx?fi=157\&doc_id=9401). This strategy of negotiating peace with one's enemies until sufficient strength is mobilized to annihilate them is thus cast in stone. 
In subtler ways this principle may entail infiltrating ones enemies using their treasured values like democracy, respect for human and "minority" rights, affirmative action and ultimately conquer them without using any physical violence (Youssef, 2017). That global intelligence and security agencies have given this model which, this paper prefers to refer to as intelligent jihad a wide berth despite its apparent success in pacifying terrorism victims, is baffling. Only time will tell if global democracies founded on Judeo-Christian civilization and have chosen the path of "blind political correctness" against plausible indicators of danger will outsmart the strategists behind this intrinsic invasion. Youssef (2017) makes the point that western civilizations should awaken to the reality that radical Islamists cannot be turned from their ways of destruction because these ways are inherent in their religious doctrine and traditions. Is it therefore possible that the motivation for jihadists to destroy lives at the high risk of losing their own is the promise in Quran 44:51-56; 52:17-20 and 55:46-78 of eventual eternal bliss in beautiful gardens in the company of beautiful virgins that no jinn or man has ever touched?

\section{Conclusions and Recommendations}

Contrary to popular opinion in liberal and leftist democracies in the world, the Quran verses outlined in this paper appear to suggest that Islam is not friendly to non-Muslims, who are referred to as either infidels, disbelievers, polytheists, pagans and idolaters. This assertion can however be verified or debunked through independent and indepth research of Islamic doctrine and traditions. Based on how governments around the world have reacted to terrorism-related crimes, it would seem as though majority of them have been blinded by political and religious correctness, and pacified through the taqqiya principle - wherein Islam is vigorously defended as a religion of peace contrary to available evidence of terrorism crimes whose responsibility has often been taken by people who profess the Islamic religion. Further, it is also very unlikely that factors like economic marginalization, poverty and unemployment are the causes of religion-driven terrorism. Attributing terrorism to radicalization per se may also not hold water because this is largely hinged on fidelity to religious doctrine and traditions. This is a subject area that policy makers, scholars and security experts around the world would need to pay a rather keen attention to. Failure to tackle terrorism based on religious motivations and relying instead on the opinions of "acclaimed religious" scholars alone is unlikely to yield sustainable security solutions since in such circumstances the taqqiya principle must be effectively used.

Instead of governments focussing on the messenger alone (i.e. the terrorist) in counter-terrorism measures, focus should now shift to include the message the terrorist may have embraced and seek to enforce to the letter. Therein may be the root cause of messengers' motivation to kill and even get killed with the promise of a better reward thereafter. Whether Islam is being falsely linked to terrorism or not calls for independent research covering both doctrine and traditions and documented incidences of terrorism around the world. The research team in this context would need to exclude religious leaders from Islam itself, Christianity and Judaism in order to eliminate biases that may occur due to conflict of interests. This way myths and propaganda will be separated from facts and truth, thus providing the international community with better insights towards counter-terrorism measures for sustainable peace and security management. 


\section{References}

Alcamo et al., (2003). Ecosystems and Human Well-being: a framework for assessment. Millennium Ecosystem Assessment. Island Press, Washington.

Caschetta, A J. (2015). Does Islam Have a Role in Suicide Bombings? Middle East Quarterly. Source: http://www. meforum.org/5320/islam-suicide-bombings (accessed in Oct 2015).

Chambers, R. (1983). Rural Development: Putting the Last First. Harlow: Prentice Hall

CNN (2020). Three teachers killed in suspected militant attack on Kenya primary school. https://edition.cnn. com/2020/01/13/africa/teachers-killed-in-kenya-militant-attack/index.html (Accessed $5^{\text {th }}$ Feb 2020).

Das E, Bushman B J, Bezemer M D, Kerkhof P, and Vermeulen I E. (2009). How terrorism news reports increase prejudice against outgroups: A terror management account. Journal of Experimental Social Psychology 45: 453-459

English R. (2016). The Future of Terrorism. European Journal of International Security, 1 (2): 135-149. DOI:10.1017/ eis.2016.6

Forbush, W B. (ed). (1926): Fox's Book of Martyrs. A History of the Sufferings and Triumphant deaths of the early Christian and Protestant Martyrs. Zondervan Publishing House.

Joan Peters (1984). From Time Immemorial. The origins of the Arab-Jewish Conflict over Palestine. JKAP Publishers, USA.

Hammond P. (2010). Slavery, Terrorism and Islam. (http://www.amazon.com/Slavery-Terrorism-Islam-PeterHammond/dp/1612154980) accessed in March 2016.

http://erlc.com/issues/quick-facts/persecution/ (accessed in March 2016)

http://nso.nato.int/nso/zPublic/ap/aap6/AAP-6.pdf (accessed in July 2016)

http://www.bbc.com/news/world-asia-35910124 (accessed on 29th March, 2016)

http://www.merriam-webster.com/dictionary/terrorism (accessed in July 2016)

http://www.state.gov/documents/organization/65464.pdf (accessed in July 2016)

https://www.cia.gov/library/publications/resources/9-11-tenth-anniversary/9-11-Brochure.pdfsource (accessed on $25^{\text {th }}$ July 2016)

https://www.google.com/\#q=jihad+definicion (accessed in July 2016)

https://www.hrw.org/world-report/2016/country-chapters/kenya (accessed in July 2016)

Lindsey H. (2002 and 2011). The Everlasting Hatred: The Roots of Jihad, Oracle House Publishing.

Muhammad Muhsin Khan and Muhammad Taqi-ud-Din Al-Hilali (1996). Interpretations of the meanings of The Noble Quran in the English Language, Darussalam.

Neumann, P R. (2008). Compass 2020. Terrorism in the 21st century. The rule of law as a guideline for German policy. Friedrich Ebert Stiftung. http://library.fes.de/pdf-files/iez/06063.pdf (accessed on 17th December 2016)

Natan Y. (ND). 164 Jihad Verses in the Koran. https://www.answering-islam.org/Quran/Themes/jihad_passages. html (Accessed 5th Feb 2020)

Omar, C. (2016). http://news.xinhuanet.com/english/africa/2013-09/23/c_132740938.htm (accessed in March 2016)

Palestinian Media Watch - http://palwatch.org/main.aspx?fi=157\&doc_id=9401 (Accessed on 25 $5^{\text {th }}$ July 2016)

Ritchie H, Hasell J, Appel C and Roser M. (2020). “Terrorism”. Published online at OurWorldInData.org.

Retrieved from: 'https://ourworldindata.org/terrorism' [Online Resource] Feb 2020

Rother B, Pierre G, Lombardo D, Herrala R, Toffano P, Roos E, Auclair G, and Manasseh K. (2016). The Economic Impact of Conflicts and the Refugee Crisis in the Middle East and North Africa. 2016. (accessed on $16^{\text {th }}$ August 2017) from: https://www.imf.org/external/pubs/ft/sdn/2016/sdn1608.pdf) 
Shayesteh D. (2009). Islam: The House I left Behind. $21^{\text {st }}$ Century Press.

Swagart J. (2010). The Writing on the wall. DVD. www.jsm.org, Baton Rouge, USA.

Taqiyah. Accessed on $16^{\text {th }}$ August 2017 from http://www.islamic-laws.com/taqiyah.htm

The East African (2020). Al-Shabaab attacks challenge counter terrorism strategies https://www.theeastafrican. co.ke/news/ea/Al-Shabaab-attacks-challenge-counter-terrorism-strategies/4552908-5423974-euaov7/ index.html (Accessed 5th Feb 2020)

Terror Stabbings in Israel. Accessed on 16 ${ }^{\text {th }}$ August 2017 from http://edition.cnn.com/2017/07/21/middleeast/ old-city-prayer-restrictions-imposed/index.html

The Economic Impact of Europe's Refugees. http://www.euronews.com/2016/11/01/refugees-in-germany-fromdesperation-to-economic-fortune (accessed on 16 $6^{\text {th }}$ August 2017).

The Holy Quran. Translation and Commentary by Abdullah Yusuf Ali. Goodword Books. Reprinted 2011.

The Qur'an in English Translation Complete Based on the translation of F. Malik in electronic format, Adapted and presented by MidEastWeb for Coexistence, http://www.mideastweb.org

United States Commission on International Religious Freedom (2019) Annual Report. https://www.uscirf.gov/ sites/default/files/2019USCIRFAnnualReport.pdf (Accessed on 5th Feb 2020)

West Minister Terror Attack (http://www.bbc.com/news/uk-39365569) accessed on 16 ${ }^{\text {th }}$ August 2017)

World Watch Institute (2005). State of the World. Redefining Global Security. Norton, New York.

Youssef M. (2017). The Barbarians Are Here: Preventing the Collapse of Western Civilization in Times of Terrorism. Worthy Publishers.

\section{About the Author}

Fuchaka Waswa is faculty, School of Agriculture and Enterprise Development, Kenyatta University.

Email contact: waswa.fuchaka@ku.ac.ke 